Original Paper http://ajol.info/index.php/ijbcs http://indexmedicus.afro.who.int

\title{
Pheno-morphological diversity of Haitian taro cultivars
}

\author{
Junior ARISTIL $^{1 *}$ and Luger JEAN SIMON ${ }^{2}$ \\ ${ }^{1}$ Centre de Recherche Interdisciplinaire pour la Vulgarisation Agricole et le Développement Local \\ (CREIVADEL), Université Notre Dame d'Haït, Faculté d'Agronomie, BP: HT 8110, Redon, Torbeck, Sud \\ d'Haïti. \\ ${ }^{2}$ American University of the Caribbean (AUC). Route Nationale No. 2, Charpentier, Les Cayes, Haïti. HT 8110. \\ "Corresponding author; E-mail: junior2aris@gmail.com; Tel: (+ 509) 4692 3173/41 539057
}

\begin{abstract}
Taro corm is consumed in Haiti as a sustain against malnutrition, but no study was so far reported about Haitian taro. An ongoing breeding program, aimed at supporting corm production, includes the present investigations on taro. Eleven taro accessions sampled in 9 departments of Haiti were tested at Torbeck from January to August 2018. Seven variables were considered and treated with SPSS. Significant $(p<0.05)$ differences appeared for three of the seven considered traits. Corm marketable yield varied from 2.97 to 12.79 $\mathrm{t} / \mathrm{ha}(\mathrm{p}<0.05)$, the locations with the largest yield being Coteaux (South department, $12.79 \mathrm{t} / \mathrm{ha}$ ), Petite- Riviére de Nippes (Nippes department, $7.56 \mathrm{t} / \mathrm{ha}$ ) and Jacmel (South East department, $7.01 \mathrm{t} / \mathrm{ha}$ ). Corm marketable yield was significantly $(p<0.001)$ and directly related with weight of corm per plant $(\rho=0.999)$, leaf length $(\rho$ $=0.924)$ and leaf width $(\rho=0.795)$. Haitian taro cultivars were divided in three separate clusters. The largest differences concerned taro accessions from Grande Rivière du Nord and Coteaux. The results of this study show that accessions from Coteaux, Petite Riviére de Nippes and Jacmel should be recommended in the plant selection program to increase corm production in Haiti.
\end{abstract}

(C) 2018 International Formulae Group. All rights reserved.

Keywords: Taro, marketable yield, diversity, cultivars, Haiti.

\section{INTRODUCTION}

Taro (Colocasia esculenta (L.) Schott) is an important corm crop species of the Araceae monocotyledonous family that grows in almost every tropical region of the world (Jianchu, 2001). The family includes approximately 110 genera and 200 species (Modi, 2007). Moreover, taro is one of the oldest crops cultivated for its edible corms and leaves, which are rich in nutrients (Boampong et al., 2018). The taro corm is an excellent source of carbohydrates and a staple crop for the peoples of the Caribbean Region,
Southeast Asia, India, Oceania and West Africa (Deo et al., 2009).

Compared to other crops, such as yams, maize and sorghum, reports on taro products from various world regions, above all the Caribbean, are scarce, the most important papers being mainly focused on fertilization studies (Osorio et al., 2003; Lee et al., 2016). Other authors reported studies on the properties of taro and sweet potatoes flours (Njintang et al., 2008; Oluwalana et al., 2012), and on the effect of plant density on yield and yield variables (Gebre et al., 2015; Suminarti 
et al., 2016). As to the author's knowledge, the most recent studies about the agromorphological and genetic diversity are those conducted by (Beyene, 2013; Nguluta et al., 2016; Kathayat et al., 2018).

Taro is one of the most important corm crops cultivated in almost all the 10 departments of Haiti, where it is consumed, either as corms or leaves, accompanied with beans and many other crops. Unfortunately, disease outbreaks infected leaves and corms shrinking the production of taro in Haiti in the last 10 years.

In spite of the relevant need, there is no investigation on the genetic diversity of Haitian taro cultivars.

The present research aimed at evaluating the pheno-morphological diversity of taro cultivated by Haitian farmers in order to acquire information for an ongoing breeding program and a future genetic improvement.

\section{MATERIALS AND METHODS Study site}

The experiment investigations were carried out at the agricultural farm of the University Notre Dame of Haiti (UNDH), (Torbeck $18^{\circ} 10^{\prime} \mathrm{N}, 73^{\circ} 49^{\prime} \mathrm{W}, 13 \mathrm{~m}$ altitude, one of the most important Haitian sites of taro cultivation until the beginning this century) from January to August 2018.

\section{Tested materials}

Local taro cultivars were used for the experimentation. A total of 11 biological products were sampled in 9 of the 10 departments of Haiti (Table 2 and Figure 1). In the South department, two kinds of samples were collected at Coteaux (SO) and Les Cayes (SC), respectively. Also in Nippes department, two different products were sampled at Anseà-Veau (NA) and Petite Riviére de Nippes (SF). The others products were sampled in Grand'Anse, Jérémie (JE), South East, Jacmel (SJ), North, Grande Riviére du Nord (GN), North West, Mole Saint Nicolas (NO), Artibonite, Saint Marc (AR), West, Léogâne (OP), and Centre, Hinche (PC). These products were sampled directly from the farmers' fields. All the collected products showed the same visual characteristics, like green leaf without signs of disease infection such as taro leaf blight. The products were sterilized, sealed in plastic bags, transported to the College of Agriculture of UNDH farm and stored until the planting date. A solution of Dithane M45 was used to sterilize the products: as suggested by the manufacturer, the solution was prepared with $6 \mathrm{~g}$ of Dithane M45 in $3780 \mathrm{~mL}$ of water. Tested materials were about 3-month old.

\section{Field trials and plant management}

The experiment design consisted of a three-replicate randomized complete block with 11 materials, in disposition of $3 \times 11$ (blocks $\mathrm{x}$ locations). Each experimental plot was planted (line $\mathrm{x}$ line: $0.50 \mathrm{~m} \times 0.80 \mathrm{~m}$ ). Each plot had $1.5 \mathrm{~m}$ by $4 \mathrm{~m}$ for a total of 15 plants ( 3 x 5: lines x rows). All the 15 plants per plot were placed on a total area of $6 \mathrm{~m}^{2}$ corresponding to a planting density of 25000 plants per ha. Taro samples were previously incubated in a solution of Emthane for 24 hours before planting. All plant samples were grown with similar agricultural practices. Three hand weeding operations were performed respectively 30,41 and 65 days after planting (Koné et al., 2010). One fertilization treatment was carried out 30 days after sowing. The total amounts of Nitrogen $(\mathrm{N})$, Phosphorus $\left(\mathrm{P}_{2} \mathrm{O}_{5}\right)$ and Potassium $\left(\mathrm{K}_{2} \mathrm{O}\right)$ were 60,40 and $20 \mathrm{~kg} / \mathrm{ha}$, respectively. Pest management treatments were performed according to the needs of the experiments. Harvest was carried out by hand 7 months after planting.

\section{Data collection}

The measured variables included plant height $(\mathrm{PH})$, plant diameter (PD), number of leaves per plant (NLP), leaf width (LW), leaf length (LL), corm marketable yield (CMY) per ha and weight of corm per plant (WCP). Corm marketable yield was calculated with materials that had corm length $>8.5 \mathrm{~cm}$. PD and LW were measured at the base of the plant and at the third leaf, respectively. All other phenotypical traits of taro from a given location were recorded according to 
IPGR/IITA (1999) and Beyene (2013). All the traits were measured on five plants per plot. Yield of taro was calculated as yield (ton/ha) $=$ $0.025 \times$ corm marketable per plant (g) (Aristil, 2019a). The yield of harvested materials was determined for the fresh corm immediately after the harvest, by means of a Fisher balance.

\section{Statistical analysis}

The SPSS statistical package for Windows, version 22.0 (SPSS Inc.) was used for all statistical analyses. Normal distribution and homogeneity of variances were verified using the Shapiro-Wilk and the Levene's tests, prior analysis of variance (ANOVA). A two-way ANOVA was carried out using sites, genotypes and sites $\mathrm{x}$ genotypes as fixed and the Ryan-Einot-Gabriel-Welsch-F test (REGW-F) was used to detect significant differences among means (Assa et al., 2012). Pearson's rank correlation coefficients $(\rho)$ were computed for all recorded traits and the obtained results were used to build a correlation matrix. Similarity among taro cultivars was checked with Clustering Analysis (CA) using Hierarchical Cluster Method based on Euclidean distance (Crossa and Franco, 2004; Oladipo and Illoh, 2010).

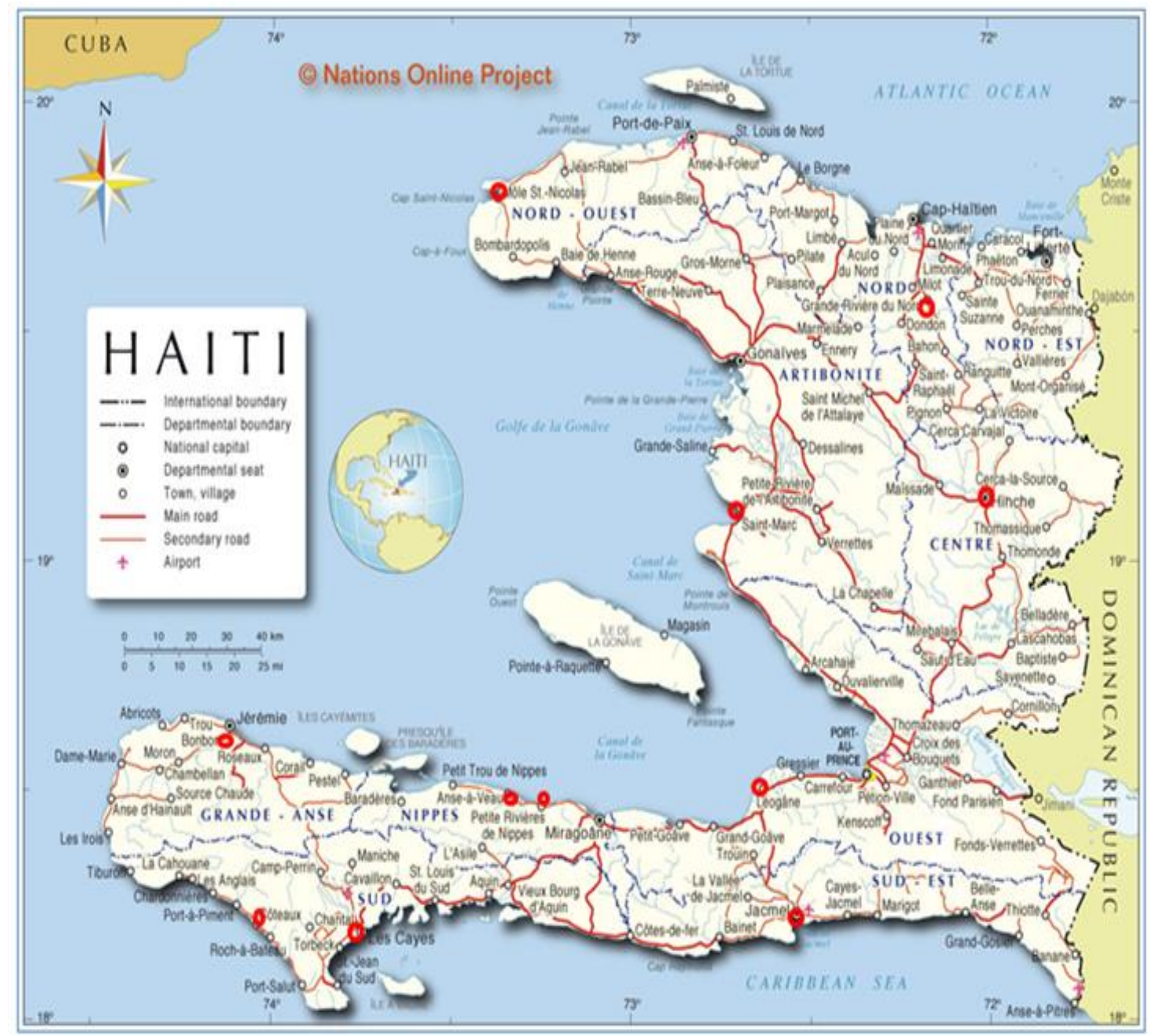

Figure 1: Administrative map of Haiti with red points indicating the origin of the sampled taro accessions. 


\section{RESULTS}

\section{Mean squares}

Mean square results obtained for the taro cultivars based on the seven registered plant characters were reported in Table 1 . Affected characters were NLP, LW and CMY, the last two (LW and CMY) showing significance at $p<0.05$, while the first (NLP) appeared as the most affected having significance at $p<0.01$. As for the blocks, only PD and NLP were significantly affected $(\mathrm{p}<0.05)$

\section{Variance}

Results of ANOVA were reported in Table 2. CMY of tested taro samples ranged from 2.97 to $12.79 \mathrm{t} / \mathrm{ha}$. The lowest and the highest CMY were registered mainly in products from Coteaux and Jérémie, respectively $(p<0.05)$. Three of the 11 tested products showed CMY larger than $7 \mathrm{t} / \mathrm{ha}$. After Coteaux (12.79 t/ha), the locations with the largest yield were Petite Rivière de Nippes (7.56 t/ha) followed by Jacmel (7.01 t/ha). No significant difference was found among the samples from the other locations ( $p>0.05$ ).

The lowest and the highest WCP were observed in products from Jacmel (88.25 g) and Jérémie (186 g), respectively. Nine of the 11 , equivalent to $81.81 \%$ of the samples, showed WCP ranging from 120 to 186 grams.

LW values were also significantly different $(\mathrm{p}<0.05)$. All the Haitian taro cultivars ranged from 12.51 to $25.77 \mathrm{~cm}$. The highest and the lowest values were found for samples from Léogâne and Saint Marc locations. All the other tested locations showed no significant $(p>0.05)$ differences for this trait.

Similar results were obtained for LL. Only the sample from Saint Marc showed a LL greater than $35 \mathrm{~cm}$. Almost $82 \%$ of tested samples showed results ranging from 20 to 27 $\mathrm{cm}$.

Maximum and minimum PD values were ranging from 9.33 to $17 \mathrm{~cm}$ in products from Saint Marc and Grand Rivière du Nord, respectively. Seven of the 11 materials collected in all the departments of Haiti revealed $\mathrm{PD}>11 \mathrm{~cm}$.
NLP of tested products ranged from 3.75 to 12.9 , namely the values observed for samples from Coteaux and Saint Marc, respectively. Only $18 \%$ of tested taro locations (2/11) showed NLP > 5 units. No significant difference was noted from 10 of the 11 tested Haitian taro cultivars. Only products from Saint Marc differ from the others ( $\mathrm{p}<0.05$ ).

The results obtained for $\mathrm{PH}$ of tested cultivars ranged from 40 to $66 \mathrm{~cm}$. More than $72 \%$ of the 11 cultivars in 9 of the 10 departments of Haiti showed $\mathrm{PH}>48 \mathrm{~cm}$. After Saint Marc $(65.67 \mathrm{~cm})$, the largest PH was recorded in Mole Saint Nicolas (56.33 $\mathrm{cm})$. The shortest products were from Léogâne and Grand Rivière du Nord with 40 and 44 $\mathrm{cm}$, respectively.

As for the coefficient of variation (CV) of tested Haitian taro cultivars, the most important were found for WCP and PH with 11123.066 and $139.346 \%$, respectively. The most stable checked parameters relevant to $\mathrm{CV}$ were PD and NLP.

\section{Correlation}

All the seven checked characters were submitted to bivariate correlation analysis. The results were reported in Table 3. The values of association among traits ranged from 0.274 to 0.999. Almost $67 \%$ of checked characters were related. The strongest correlations were detected between CMY and WCP $(\rho=0.999, p$ $<0.001)$ followed by WCP and LW $(\rho=0.925$, $\mathrm{p}<0.001)$. Besides WCP, the most important correlations of CMY were noted with LL $(\rho=$ $0.924, p<0.001)$ and LW $(\rho=0.795, p<$ $0.001)$, respectively.

More than $50 \%$ of the tested variables were correlated at $p<0.001$. On the other hand, five of the checked traits were correlated at $p<0.01$. NLP was associated with any else trait. All of the checked characters of the Haitian taro cultivars were directly correlated. $\mathrm{PH}$ was correlated with PD and with CMY.

\section{Clustering}

Tested taro cultivars of Haiti were distributed in three clusters (Figure 2). The three clusters included 1, 3 and 7 departments, respectively. The first cluster included only 
Grande Rivière du Nord. The second cluster included Hinche, Jérémie and Saint Marc. The latest group of taro cultivars was divided into two subgroups. The first subgroup was formed by Jacmel and Hinche and the second subgroup was formed by Anse-à-Veau, Petite Rivière de Nippes, Les Cayes, Mole Saint Nicolas and Coteaux. The most divergent taro products were noted in Grande Rivière du Nord and Coteaux. Regarding Figure 2, Grande Rivière du Nord is closer to Saint Marc compared to Jérémie, while Jacmel is equidistant with respect to Coteaux and Grand Rivière du Nord.

Table 1: Mean squares of registered characters.

\begin{tabular}{ccc}
\hline Plant characters & Treatments & Blocks \\
\hline Plant height $(\mathrm{cm})$ & $193.051^{\mathrm{NS}}$ & $101.549^{\mathrm{NS}}$ \\
Number of leaves per plant (u) & $21.271^{* *}$ & $42.874^{*}$ \\
Plant diameter $(\mathrm{cm})$ & $22.402^{\mathrm{NS}}$ & $65.522^{*}$ \\
Leaf length (cm) & $102.687^{\mathrm{NS}}$ & $2.393^{\mathrm{NS}}$ \\
Leaf width (cm) & $61.751^{*}$ & $0.084^{\mathrm{NS}}$ \\
Weight corm per plant (g) & $11963.408^{\mathrm{NS}}$ & $6414.769^{\mathrm{NS}}$ \\
Corm marketable yield (t/ha) & $34.145^{*}$ & $12.737^{\mathrm{NS}}$ \\
\hline *: $\mathrm{p}<0.05 ; * * \mathrm{p}<0.01$ and NS: not significant at $\mathrm{p}<0.05($ test REGW-F).
\end{tabular}

Table 2: Average values registered for each character per origin.

\begin{tabular}{cccccccc}
\hline & & \multicolumn{7}{c}{ Plant characters } \\
Origin & $\begin{array}{c}\text { PH } \\
(\mathbf{c m})\end{array}$ & $\begin{array}{c}\text { NLP } \\
(\mathbf{u})\end{array}$ & $\begin{array}{c}\text { PD } \\
(\mathbf{c m})\end{array}$ & $\begin{array}{c}\mathbf{L L} \\
(\mathbf{c m})\end{array}$ & $\begin{array}{c}\mathbf{L W} \\
(\mathbf{c m})\end{array}$ & $\begin{array}{c}\text { WCP } \\
(\mathbf{g})\end{array}$ & $\begin{array}{c}\text { CMY } \\
(\mathbf{t} / \mathbf{h a})\end{array}$ \\
\hline OP & 40 & $4.89 \mathrm{a}$ & 9.44 & 18.78 & $12.51 \mathrm{a}$ & 88.89 & $5 \mathrm{ab}$ \\
PC & 44.73 & $4 \mathrm{a}$ & 10.36 & 20.11 & $14.58 \mathrm{ab}$ & 183.64 & $4.76 \mathrm{ab}$ \\
NO & 56.33 & $4.33 \mathrm{a}$ & 11.67 & 21.5 & $15.43 \mathrm{ab}$ & 133.33 & $5.09 \mathrm{ab}$ \\
GN & 44 & $4.33 \mathrm{a}$ & 9.33 & 22.73 & $15.87 \mathrm{ab}$ & 150 & $3.85 \mathrm{ab}$ \\
SF & 48.58 & $5.33 \mathrm{a}$ & 12.42 & 24.48 & $16.16 \mathrm{ab}$ & 141.67 & $7.56 \mathrm{ab}$ \\
JE & 49.6 & $4.4 \mathrm{a}$ & 13.2 & 24.78 & $17.78 \mathrm{ab}$ & 186 & $2.97 \mathrm{a}$ \\
NA & 49.8 & $4 \mathrm{a}$ & 12.8 & 25.80 & $18.06 \mathrm{ab}$ & 120 & $6.85 \mathrm{ab}$ \\
SJ & 50.38 & $4.5 \mathrm{a}$ & 12.75 & 26.38 & $18.66 \mathrm{ab}$ & 86.25 & $7.01 \mathrm{ab}$
\end{tabular}




$\begin{array}{cccccccc}\text { SO } & 51.75 & 3.75 \mathrm{a} & 10.5 & 26.93 & 18.98 \mathrm{ab} & 130 & 12.79 \mathrm{~b} \\ \text { SC } & 50.38 & 4.46 \mathrm{a} & 13.08 & 26.4 & 19.41 \mathrm{ab} & 139.23 & 4.60 \mathrm{ab} \\ & & & & & & & \\ \text { AR } & 65.67 & 12.9 \mathrm{~b} & 17 & 35.77 & 25.77 \mathrm{~b} & 168.33 & 4.88 \mathrm{ab} \\ \mathrm{CV}(\%) & 139.346 & 16.291 & 15.209 & 54.839 & 30.983 & 11123.066 & 18.975\end{array}$

SJ: Jacmel, OP: Léogâne, NA: Anse à Veaux, SO: Coteaux, NO: Mole Saint Nicolas, SC: Sud Cayes, SF: Petite Rivière de Nippes, AR: Saint Marc, PC: Hinche, JE: Jérémie, GN: Grand Rivière du Nord. PH: plant height, NLP: number of leaves per plant, PD: plant diameter, LW: leaf width, LL: leaf length, WCP: weight of corm per plant and CMY: Corm marketable yield per ha. Characters with different letter are significantly different at $\mathrm{p}<0.05$.

Table 3: Correlation matrix of characters.

\begin{tabular}{cccccccc}
\hline & PH & NLP & PD & LL & LW & WCP & CMY \\
\hline PH & 1 & $0.360^{\mathrm{NS}}$ & $0.890^{* * *}$ & $0.872^{* * *}$ & $0.911^{* * *}$ & $0.719^{* *}$ & $0.718^{* *}$ \\
NLP & 1 & $0.274^{\mathrm{NS}}$ & $0.351^{\mathrm{NS}}$ & $0.352^{\mathrm{NS}}$ & $0.438^{\mathrm{NS}}$ & $0.437^{\mathrm{NS}}$ \\
PD & & & 1 & $0.859^{* *}$ & $0.904^{* * *}$ & $0.690^{*}$ & $0.700^{*}$ \\
LL & & & 1 & $0.351^{\mathrm{NS}}$ & $0.925^{* * *}$ & $0.924 * * *$ \\
LW & & & & 1 & $0.796^{* *}$ & $0.795^{* *}$ \\
WCP & & & & & 1 & $0.999 * * *$ \\
CMY & & & & & & & 1
\end{tabular}

PH: plant height, NLP: number of leaves per plant, PD: plant diameter, LL: leaf length, LW: leaf width, WCP: weight of corm per plant and CMY: Corm marketable yield per ha; *: $p<0.05 ; * *$ : $<0.01$; *** p $<0.001$ and NS: not significant.

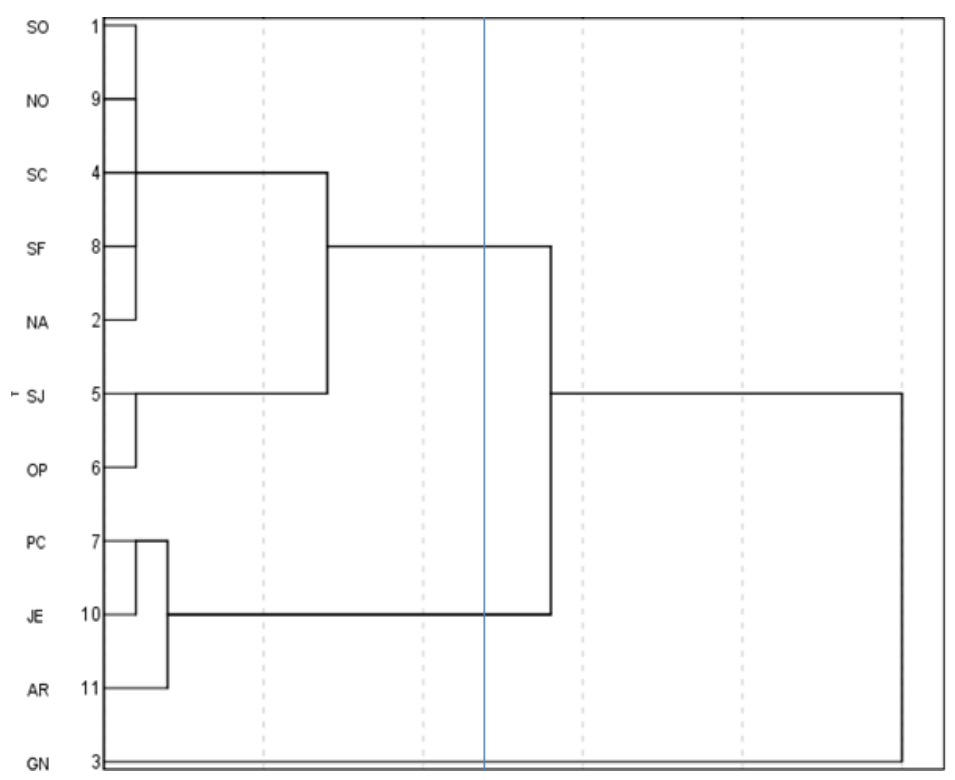

Figure 2: Dendrogram from Clustering Analysis. SJ: Jacmel, OP: Léogâne, NA: Anse à Veaux, SO: Coteaux, NO: Mole Saint Nicolas, SC: Sud Cayes, SF: Petite Rivière de Nippes, AR: Saint Marc, PC: Hinche, JE: Jérémie, GN: Grand Rivière du Nord. 


\section{DISCUSSION}

Taro is one of the most important crops in Haiti, where it is cultivated mainly for corm production. Corms and leaves of taro are consumed by a large amount of Haitian people, either rich or poor. Yet, research about Haitian taro is scarce. Studies in Haiti are particularly focused on mycotoxin contaminations (Aristil et al., 2017; Aristil, 2019b). The present study is the first one conducted on pheno-morphological characterization of Haitian taro cultivars with the aim to develop a breeding program of corm production. Seven pheno-morphological characters were registered and submitted to statistical analysis. The most influenced parameter was NLP, suggesting that this trait could be taken into account in a program with the aim to increase leaf production in Haiti. Few of the considered traits were influenced by blocks $(\mathrm{p}<0.05)$ : this finding partially differs from the data reported by other Authors (Miyasaka et al., 2003; Gerrano et al., 2019). In a study on South African taro locations during three years, Gerrano and colleagues (2019) found that all the checked traits seemed affected $(\mathrm{p}<0.01)$ by the location. This difference could be a result of the peculiar environment of the sites where taro samples were cultivated for the investigation. In the present study the samples from all locations were cultivated in the same site (Torbeck, Haiti).

There was no significant difference among taro cultivars for $\mathrm{PH}(\mathrm{p}<0.05)$, suggesting that $\mathrm{PH}$ is a resistant trait inherited by the Haitian taro from every location. This result is compatible with those of other plants, e.g., maize (Perales et al., 2005).

CMY per ha varied from 2 to $13 \mathrm{t} / \mathrm{ha}$, in line with other reports (Miyasaka, 2001; Tumuhimbise et al., 2009). The lowest and the highest CMY were found mainly in products from Coteaux and Jérémie, suggesting a considerable genetic difference between the cultivars from the two locations, as for corm yield. Moreover, three of the 11 tested products showed CMY > $7 \mathrm{t} / \mathrm{ha}$, which is much greater than $1 \mathrm{t} / \mathrm{ha}$ obtained in Uganda (Macharia et al., 2014). Almost $82 \%$ of the tested taro cultivars showed WCP ranging from 120 to 186 grams, which differs from the value reported in another study (Boampong et al., 2018) on the agro-morphological characterization of some taro (Colocasia esculenta (L.) Schott) germplasms in Ghana. These authors found corn weight ranging from 260 to 790 grams per plant. This difference could be due to the geographical origin of the products. In the present study, the tested products are all from Haitian farmers' fields, while those of the Boampong's work were from Malaysia, Indonesia, Samoa and some areas of Ghana.

LW values were also significantly different $(p<0.05)$, suggesting the presence of a genetic diversity among Haitian cultivars. Only samples from Saint Marc showed LL greater than $35 \mathrm{~cm}$, while no significant difference was observed among tested locations, in line with the findings by other author (Beyene, 2013). More investigations are however necessary to complete the present findings, as this is just the first preliminary study on the taro genetic classification in Haiti.

PD values ranged from 9 to $18 \mathrm{~cm}$. Five of the 11 products collected in all the departments of Haiti revealed PD $>11 \mathrm{~cm}$. The maximum and minimum values of NLP were observed mainly in samples from Saint Marc and Coteaux. Only products from Saint Marc were different $(p<0.05)$ from the others. These results suggest that NLP is affected by the origin of the products, in line with the reports by other authors (Lu et al., 2004).

Around $46 \%$ of the 11 Haitian tested cultivars showed $\mathrm{PH}>50 \mathrm{~cm}$. After Saint Marc with $65.67 \mathrm{~cm}$, the largest PH was found in Mole Saint Nicolas $(56.33 \mathrm{~cm})$. The results of the present research are in line with those by other authors (Manzano, 2001; Mabhaudhi et al., 2013). Moreover, as for the coefficient of variation (CV) of tested Haitian taro cultivars, PD and NLP were the most stable parameters.

Almost $67 \%$ of checked characters were correlated. The strongest correlations were detected between CMY and WCP values ( $\rho=0.999, p<0.001)$, suggesting that the most important character to use as CMY predictor is WCP with 99\% precision. Majority of phenomorphological traits of the Haitian taro cultivars were directly correlated, supposing 
that the increase of one trait corresponds to the increase of the others in the same direction. $\mathrm{PH}$ was correlated with $\mathrm{PD}$ and $\mathrm{CMY}$, in agreement with the findings by Kandel et al. (2018).

Taro cultivars of Haiti were ranked in three clusters, confirming ANOVA results that suggested differences among tested products. The three clusters had 1 and 3 and 7 locations, respectively. The first cluster included only Grande Rivière du Nord. Regarding Haitian map (Figure 1), Grande Rivière du Nord is far from almost all the other departments where samples for this study were collected. Possibly, the products from Grande Rivière du Nord came from plants cultivated in the Dominican Republic because important Haitian municipalities and departments, which are close to Dominican Republic, developed informal relationships with homologous structures, including the exchange seed varieties. The largest divergence among Haitian taro accessions was observed in Grande Rivière du Nord and Coteaux. Such findings suggest that those materials could contain desirable traits and might be used as parents in breeding program.

Hinche, Saint Marc and Jérémie formed the second cluster. These locations seem characterized by an important leaf width, suggesting the possibility of using these products in a development program aiming to the production of leaves, which are rich in nutrients and vitamins (Huang et al., 2000; Xu et al., 2001).

The other seven locations (Coteaux, Les Cayes, Jacmel, Petite Rivière de Nippes, Léogâne, Anse à Vaux and Mole Saint Nicolas) seem better related with products with the best corm yield traits. The three most important locations (Coteaux, Les Cayes, and Jacmel) as for the corm production are in this cluster. This cluster was subdivided into two subclusters reflecting some genetic diversity among the related cultivars. Petite Rivière de Nippes and Anse à Vaux materials coming from the Nippes department are an independent subcluster. Similarly, Coteaux and Les Cayes, both in the South department, are in the same subcluster. Yet, Jacmel and Léogâne locations, that belong to different departments, South East and West, provide similar products, suggesting a genetic similarity among the cultivars from the two locations (Figure 2). Possibly, these taro cultivars stem from a common ancestor and are the result of exchanges of local cultivars among Haitian farmers.

\section{Conclusion}

Taro is an important corm crops, which is cultivated in almost every tropical region of the world. Till now, there were no investigations on Haitian taro. The findings of this first study on pheno-morphological diversity of taro cultivars in Haiti reveal that the corm marketable yield of Haitian taro ranges from 2.97 to $12.79 \mathrm{t} / \mathrm{ha}$. Corm yield of Haitian taro is strongly $(\mathrm{p}<0.001)$ and positively related to weight of corm per plant and leaf width, suggesting that these traits could be used as predictive parameters of corm production in Haiti. Clustering analysis revealed that Haitian taro cultivars can be grouped in three clusters. The largest differences were noted among products from Grande Rivière du Nord and Coteaux. Products from Coteaux, Les Cayes and Jacmel, that show the largest corm yields and belong to the same cluster, could be used as parents in programs with the aim to increase corm production in Haiti. Further laboratory investigations are necessary to complete these findings, in order to promote a breeding and genetic improvement of taro cultivars in Haiti.

\section{COMPETING INTERESTS}

The authors have not declared any competing interests.

\section{AUTHOR'S CONTRIBUTIONS}

JA performed samples collection, field trial, data collection and analysis and, write the materials and methods part. LJS assure the introduction. Both authors complete the discussion and conclusion, and the final revision of the document.

\section{ACKNOWLEDGEMENTS}

Deep thanks to Marcus Garvey SENATUS for his contribution and assistance during field management. 


\section{REFERENCES}

Ali Q, Ahsan M. 2015. Correlation analysis for various grain contributing traits of Zea mays. African Journal of Agricultural Research, 10(23): 2350$2354 . \quad$ DOI: https://doi.org/10.5897/AJAR2013.7838

Aristil J. 2019. Aflatoxin contamination of baby food flour sold on Haitian markets. Int. J. Biol. Chem. Sci., 13(3): 1821$1825 . \quad$ DOI: https://dx.doi.org/10.4314/ijbcs.v13i3.49

Aristil J, Venturini G, Spada A. 2017. Occurrence of Toxigenic Fungi and Aflatoxin Potential of Aspergillus spp. Strains Associated with Subsistence Farmed Crops in Haiti. J. Food Prot., 80(4): 626-631.

Aristil J. 2019. Effets de trois types de fertilisants sur les paramètres végétatifs et productifs du sorgho en Haïti. Int. J. Biol. Chem. Sci., 13(2): 720-726. DOI: https://dx.doi.org/10.4314/ijbcs.v13i2.12

Assa RR, Konan JL, Prades A, Nemlin J. 2012. Caractéristiques gustatives de l'eau des fruits de quatre cultivars du cocotier (Cocos nucifera L.). Int. J. Biol. Chem. Sci., 6(6): 3045-3054.

Beyene TM. 2013. Morpho-agronomical characterization of taro (Colocasia esculenta) accessions in Ethiopia. Plant, 1(1): $1-9 . \quad$ DOI: 10.11648/j.plant.20130101.11

Boampong R, Aboagye LM, Nyadanu D, Esilfie M. 2018. Agro-morphological characterization of some taro (Colocasia esculenta (L.) Schott.) germplasms in Ghana. Journal of Plant Breeding and Crop Science, 10(8): 191-202. DOI: 10.5897/JPBCS2018.0734

Crossa J, Franco J. 2004. Statistical methods for classifying genotypes. Euphytica, 137(1): 19-37.

Deo PC, Harding RM, Taylor M, Tyagi AP, Becker DK. 2009. Somatic embryogenesis, organogenesis and plant regeneration in taro (Colocasia esculenta var. esculenta). Plant Cell, Tissue and Organ Culture (PCTOC), 99(1) : 61-71.

Gebre A, Tesfaye B, Kassahun BM. 2015. Effect of corm size and plant population density on corm yield of Taro (Colocasia esculenta L.). International Journal of Advanced Biological and Biomedical Research, 3(4): 405-412.

Gerrano AS, Jansen VRWS, Adebola PO, Manjeru P, Bairu MW, Venter SL. 2019. Evaluation and selection of taro [Colocasia esculentra (L.) Schott] accessions under dryland conditions in South Africa. Acta Agriculturae Scandinavica, Section B-Soil \& Plant Science, 69(3): 219-227. DOI: https://doi.org/10.1080/09064710.2018.1 530296

Huang AS, Titchenal CA, Meilleur BA. 2000. Nutrient composition of taro corms and breadfruit. Journal of food composition and analysis, 13(5): 859-864.

IPGRI/IITA. 1999. Decriptors for taro, (Colocasia sp.). International Institute for Tropical Agriculture, Ibadan, Nigeria/International Plant Genetic Resource Institute, Rome, Italy 56 p.

Jianchu X, Yongping Y, Yingdong P, Ayad WG, Eyzaguirre PB. 2001. Genetic diversity in taro (Colocasia esculenta Schott, Araceae) in China: An ethnobotanical and genetic approach. Economic Botany, 55(1): 14-31.

Kandel M, Ghimire SK, Ojha BR, Shrestha J. 2018. Correlation and path coefficient analysis for grain yield and its attributing traits of maize inbred lines (Zea mays L.) under heat stress condition. International Journal of Agriculture, Environment and Food Sciences, 2(4): 124-130. DOI: https://doi.org/10.31015/jaefs.18021

Kathayat K, Kushwaha ML, Rawat M. 2018. Estimation of genetic diversity in taro (Colocasia esculenta (L.) Schott. Var. antiquorum) germplasm using principal component analysis and cluster analysis. Journal of Pharmacognosy and Phytochemistry, 7(3) : 2034-2038.

Koné B, Yao-Kouamé A, Sorho F, Diatta S, Sié M, Ogunbayo A. 2010. Long-term effect of Mali phosphate rock on the grain yield of interspecifics and saltiva rice cultivars on acid soil in a humid forest zone of Côte d'Ivoire. Int. J. Biol. Chem. Sci., 4(3): 563-570.

Lee YJ, Sung JK, Lee SB, Lim JE, Song YS, Lee DB. 2016. Fertilizer Use Efficiency 
of Taro (Colocasia esculenta Schott) and Nutrient Composition of Taro Tuber by NPK Fertilization. Korean Journal of Soil Science and Fertilizer, 49(4): 388392.

DOI:

http://dx.doi.org/10.7745/KJSSF.2016.49 .4 .388

Lu HY, Lu CT, Wei ML, Chan LF. 2004. Comparison of different models for nondestructive leaf area estimation in taro. Agronomy Journal, 96(2): 448-453. DOI:10.2134/agronj2004.4480

Mabhaudhi T, Modi AT, Beletse YG. 2013. Response of taro (Colocasia esculenta $\mathrm{L}$. Schott) landraces to varying water regimes under a rainshelter. Agricultural water management, 121: 102-112. DOI: https://doi.org/10.1016/j.agwat.2013.01.0 09

Macharia MW, Runo SM, Muchugi AN, Palapala V. 2014. Genetic structure and diversity of East African taro [Colocasia esculenta (L.) Schott]. African Journal of Biotechnology, 13(29).

Manzano AR, Nodals AAR, Gutiérrez MIR, Mayor ZF, Alfonso LC. 2001. Morphological and isoenzyme variability of taro (Colocasia esculenta L. Schott) germplasm in Cuba. Plant genetic resources newsletter, 31-40.

Miyasaka SC, Ogoshi RM, Tsuji GY, Kodani LS. 2003. Site and planting date effects on taro growth. Agronomy journal, 95(3): 545-557.

Modi AT. 2007. Effect of indigenous storage method on performance of taro [Colocasia esculenta (L.) Schott] under field conditions in a warm subtropical area. South African Journal of Plant and Soil, 24(4): 214-219. DOI: 10.1080/02571862.2007.10634812

Nguluta M, Adebola P, Pillay M. 2016. Genetic diversity analysis in South African taro (Colocasia esculenta) accessions using molecular tools. International Journal of Genetics and Molecular Biology, 8(4) : 18-24.

Njintang YN, Scher J, Mbofung CMF. 2008. Physicochemical, thermal properties and microstructure of six varieties of taro (Colocasia esculenta L. Schott) flours and starches. Journal of Food Engineering., 86(2): 294-305. DOI: https://doi.org/10.1016/j.jfoodeng.2007.1 0.006

Oladipo OT, Illoh HC. 2010. Pollen morphology and diversity in some Nigerian species of Jatropha L.(Euphorbiaceae). Int. J. Biol. Chem. Sci., 4(3): 546-554. DOI: http://dx.doi.org/10.4314/ijbcs.v4i3.6044 8

Oluwalana IB, Malomo SA, Ogbodogbo EO. 2012. Quality assessment of flour and bread from sweet potato wheat composite flour blends. Int. J. Biol. Chem. Sci., 6(1): $\quad 65-76 . \quad$ DOI: http://dx.doi.org/10.4314/ijbcs.v6i1.6

Osorio NW, Shuai X, Miyasaka S, Wang B, Shirey RL, Wigmore WJ. 2003. Nitrogen level and form affect taro growth and nutrition. HortScience, 38(1): 36-40.

Perales HR, Benz BF, Brush SB. 2005. Maize diversity and ethnolinguistic diversity in Chiapas, Mexico. Proceedings of the National Academy of Sciences, 102(3): 949-954. DOI:10.1073_pnas.0408701102

Suminarti NE, Ariffin GB, Rayes ML. 2016. Effect of fertilizer application and plant density on physiological aspect and yield of taro (Colocasia esculenta (L.) Schott var. Antiquorum). Int. J. Agric. Res., 11(1): 32-39. DOI: 10.3923/ijar.2016.32.39

Tumuhimbise R, Talwana HL, Osiru DSO, Serem AK, Ndabikunze BK, Nandi JOM, Palapala V. 2009. Growth and development of wetland-grown taro under different plant populations and seedbed types in Uganda. African Crop Science Journal, 17(1).

$\mathrm{Xu} \mathrm{J}$, Yang Y, Pu Y, Ayad WG, Eyzaguirre PB. 2001. Genetic diversity in taro (Colocasia esculenta Schott, Araceae) in China: An ethnobotanical genetic approach. Economic Botany, 55(1): 14. 